Vol 1 No 22020 Desember 2020

Jurnal AlphaEuclidEdu

Received: 21/10/2020; Revised: 30/11/2020; Accepted: 08/12/2020

\title{
PENGEMBANGAN BAHAN AJAR INTERAKTIF UNTUK PEROLEHAN KETERAMPILAN PADA MATERI LINGKARAN
}

\author{
${ }^{1}$ Ulya, Ulvi, ${ }^{2}$ Suratman, Dede, ${ }^{3}$ Nursangaji, Asep \\ 1,2,3 Pendidikan Matematika FKIP Universitas Tanjungpura Pontianak \\ Email: uulya.96@gmail.com
}

\begin{abstract}
This research aims to determine the feasibility of interactive teaching materials that are developed, and how intellectual skills of students after using teaching materials that are developed. The research method used is descriptive. The subjects of this research were 24 students from class XI SMP Islam Bawari Pontianak. The data source of this research were the student test answers sheet, and the validation sheet for the feasibility of interactive teaching materials. The results showed that interactive teaching materials were declared to be very valid, refer to material experts and media experts. The students' intellectual skills of relationship the central angle with length of arc is $58.33 \%$ in the sufficient category. The students' intellectual skills of relationship the central angle with area of circle sector is $50 \%$ in the sufficient category. The students' intellectual skills of solve problems related to the central angle, inscribed angle, length of arc, and area of circle sector, and its relationship is $20.83 \%$ in the low category.
\end{abstract}

Keywords: Circles, Intellectual Skills, Interactive Teaching Materials

\section{Pendahuluan}

Materi pembelajaran ialah satu diantara muatan pembelajaran yang diperlukan dalam proses belajar mengajar supaya tujuan pembelajaran bisa tercapai. Nana dan Ibrahim mengungkapkan bahwa materi pembelajaran adalah suatu yang disuguhkan guru untuk ia proses dan selanjutnya dipahami oleh siswa, untuk mencapai tujuantujuan instruksional yang sudah ditentukan (dalam Abi, 2012). Depdiknas (2006:4) mengatakan bahwa bahan ajar maupun materi pembelajaran pada umumnya berisi pengetahuan, keterampilan, dan sikap yang wajib dipelajari siswa untuk memenuhi standar kompetensi yang ada. Dari pendapat tersebut, peneliti menyarikan bahan ajar yakni seperangkat materi pelajaran yang bisa menolong terpenuhinya tujuan kurikulum yang dibuat secara terurut dan lengkap agar menciptakan suasana belajar yang mengasyikkan, mempermudah siswa belajar, dan guru mengajar.

Sementara itu, Prastowo menyatakan bahwa fakta dilapangan, terdapat guru yang masih menerapkan bahan ajar konvesional, berupa bahan ajar yang siap digunakan, serta tanpa proses perencanaan (Prastowo, 2011). Oleh karena itu, resiko sangat memungkinkan apabila bahan ajar yang digunakan belum konstekstual, kurang menarik, menoton, serta belum sesuai dengan kebutuhan siswa. Hal ini dialami peneliti saat menjalankan Praktik Pengalaman Lapangan (PPL) di SMP Islam Bawari Pontianak. Bahwa dalam proses pembelajaran khususnya matematika, guru masih menerapkan bahan ajar konvensional berupa Buku Sekolah Elektronik (BSE).

Menurut peneliti, buku tersebut masih kurang memadai kebutuhan siswa, hal ini ditunjukkan dari keluhan siswa yang kurang memahami materi dalam buku tersebut, terutama pada pilihan kata yang digunakannya. 
Vol 1 No 22020 Desember 2020

Jurnal AlphaEuclidEdu

Sehingga siswa mengalami kesulitan untuk menyelesaikan soal matematika, terutama soal bagian keterampilan. Peneliti juga mewawancarai guru matematika di sekolah, beliau menyatakan saat proses pembelajaran berlangsung, terutama pada materi lingkaran, banyak siswa yang kurang fokus, tidak memperhatikan serta ada yang berbicara. Ini mengakibatkan siswa susah mengerti materi yang diajarkan guru, terutama saat menentukan sudut pusat,panjang busur, dan luas juring lingkaran, sehingga hasil belajarnya belum memuaskan. Bahan ajar yang digunakan guru tersebut kurang memadai.

Terdapat hal yang menarik ketika peneliti mengajar di sana. Peneliti membuat sebuah media pembelajaran, yaitu power point. Saat mengajar dengan media tersebut, siswa banyak yang memperhatikan bahkan semuanya ikut berkontribusi dalam materi yang disampaikan. Dan siswa cenderung memahami materi yang telah disampaikan oleh peneliti. Sehingga siswa bisa mengerjakan soal matematika, terutama bagian keterampilan. Oleh karena itu, peneliti berpendapat bahwa bahan ajar yang digunakan guru saat ini kurang memadai. Oleh karena itu, peneliti tertarik mengembangkan sebuah bahan ajar untuk menunjang kegiatan belajar dan pembelajaran.

Banyak teknologi yang telah berkembang pada zaman ini. Untuk membuat media pembelajaran pun tidak hanya dengan power point. Contoh teknologi yang dapat menunjang belajar siswa adalah 3D PageFlip. 3D PageFlip ini adalah sebuah aplikasi berupa buku elektronik, dengan tampilan berupa buku secara nyata. Namun bisa ditambahkan dengan audio, video, dan lainnya. Program 3D PageFlip mudah digunakan, fitur-fiturnya sederhana, namun hasilnya memuaskan.

Prastowo mengungkapkan bahwa bahan ajar terbagi dari bentuk, cara kerja, dan sifat. Dari bentuknya, terbagi menjadi 4 macam yakni: (1) bahan cetak (printed); (2) bahan ajar dengar atau program audio; (3) bahan ajar pandang dengar (audiovisual); (4) bahan ajar interaktif (Prastowo, 2012). Bahan ajar yang ingin peneliti kembangkan ialah bahan ajar interaktif. Prastowo menyatakan bahwa bahan ajar interaktif bisa dikelompokkan menjadi dua, yaitu Compact Disk (CD) interaktif dan orang (Prastowo, 2012). Dalam penelitian ini peneliti memilih menciptakan bahan ajar interaktif dalam bentuk CD interaktif. Sehingga bahan ajar yang dikembangkan akan dimuat dalam sebuah $\mathrm{CD}$, agar mudah digunakan.

Sehingga peneliti ingin mengembangkan sebuah bahan ajar interaktif dengan menggunakan program 3D Pageflip, dan dimuat dalam sebuah CD. Materi yang dipilih ialah lingkaran, dengan submateri sudut pusat, panjang busur, dan luas juring lingkaran. Bahan ajar interaktif yang sudah dikembangkan, akan dilihat kelayakannya dan bagaimana keterampilan intelektual siswa sebelum dan sesudah menerapkan bahan ajar. Karena penelitian ini berupa pengembangan, peneliti berpatokan dengan prosedur penelitian pengembangan Sugiyono. Sugiyono menyatakan bahwa terdapat 10 tahapan dalam penelitian pengembangan, yaitu: (1) Potensi dan Masalah; (2) Pengumpulan Data; (3) Desain Produk; (4) Validasi Desain; (5) Revisi Desain; (6) Ujicoba Produk; (7) Revisi Produk; (8) Ujicoba Penggunaan; (9) Perbaikan Produk; (10) Pembuatan 
Vol 1 No 22020 Desember 2020

Jurnal AlphaEuclidEdu

Produk Masal (Sugiyono, 2017). Namun, pada penelitian ini, peneliti hanya melewati tahap 1 hingga 7 . Berikut penjelasannya.

\section{Potensi dan Masalah}

Adanya masalah atau potensi dapat dijadikan landasan suatu penelitian. Potensi ialah ragam hal yang jika diberdayagunakan akan mempunyai nilai lebih. Contohnya, di pantai selatan pulau jawa, ada potensi sinar matahari dan angin, yang keduanya bisa ditingkatkan menjadi energi mekanik yang bisa dipakai dalam memobilisasi sesuatu.

\section{Pengumpulan Data}

Selepas potensi dan masalah bisa ditampilkan secara objektif dan terkini, kemudian harus dihimpun beragam informasi yang bisa dipakai menjadi bekal dalam perancangan produk yang diinginkan bisa menangani masalah itu.

\section{Desain Produk}

Sesudah melakukan pengumpulan data, dilanjutkan dengan desain produk. Desain produk yang dibuat peneliti harus lengkap dengan spesifikasinya, dan ditampilkan dalam gambar atau bagan, agar bisa dipakai semacam patokan dalam menilai dan membuatnya.

\section{Validasi Desain}

Validasi desain ialah proses untuk mengetahui kefektifan rancangan produk yang dibuat. Validasi ini tetap berupa penilaian dari pendapat logis, tanpa kenyataan lapangan. Validasi produk bisa dilakukan dengan menemui spesialis yang telah berpengalaman dalam mengukur produk baru yang dibuat.

\section{Revisi Desain}

Sesudah desain produk dan validasi desain terlewati, lalu dapat diketahui kekurangannya. Selanjutnya kekurangan itu dikurangi dengan cara menyunting desain.

\section{Ujicoba Produk}

Dalam dunia pendidikan, desain produk bisa lantas diuji coba, sesudah divalidasi dan diperbaiki. Uji coba fase awal dilaksanakan berupa simulasi. Sehabis disimulasikan, maka boleh diujicobakan dalam kelompok terbatas. Tujuan uji coba dilakukan agar memperoleh informasi apakah aplikasi yang dibuat berdaya guna baik.

\section{Revisi Produk}

Revisi produk dilakukan jika salah satu hal yang diujikan belum memenuhi target yang diinginkan. Sehingga produk direvisi kembali. Jika pengujicobaan awal berhasil lebih efektif dan efisien, maka peneliti bisa menerapkannya di ruang lingkup yang lebih luas tempat sampel diambil.

Guidelines for Bibliographic Description of Interaktive Multimedia menyatakan bahwa Bahan ajar interaktif merupakan gabungan dari dua atau lebih media (audio, teks, grafik, gambar, dan video) oleh penggunanya dimanipulasi untuk mengontrol perintah dan atau perbuatan alami dari suatu presentasi (dalam Prastowo, 2012). Program yang digunakan peneliti yaitu 3D Pageflip, yang juga bisa mengkombinasikan dua atau lebih media. Peneliti mengkombinasikan audio, teks, dan gambar dalam bahan ajar interaktif. Kemudian Munir menyatakan karakteristik dari media pembelajaran multimedia 
Vol 1 No 22020 Desember 2020

Jurnal AlphaEuclidEdu

interaktif adalah: (1)Memiliki lebih dari satu media yang konvergen, misalnya menggabungkan unsur audio dan visual; (2) Bersifat interaktif, memiliki kemampuan mengakomodasi respons pengguna; (3) Bersifat mandiri, memberi kemudahan dan kelengkapan isi sehingga pengguna bisa menggunakan tanpa bimbingan orang lain (Munir, 2012). Untuk kelayakan bahan ajar interaktif yang dikembangkan, peneliti mengacu pada BSNP (Badan Standar Nasional Pendidikan) sebagai kelayakan materi dan pembelajaran, serta Yudhi Munadi sebagai kelayakan media. BSNP (Badan Standar Nasional Pendidikan) mengungkapkan bahwa ada 4 komponen yang dinilai untuk menentukan kelayakan bahan ajar yaitu: (1) kelayakan isi; (2) kelayakan bahasa; (3) kelayakan penyajian; (4) kelayakan kegrafikkan (BSNP, 2007). Namun peneliti hanya menggunakan 3 komponen, berikut penjelasannya.

\section{Kelayakan isi}

Muatan kelayakan isi ini dipecah dalam indikator yakni: (1) alignment dari SK dan KD mata pelajaran, pertumbuhan anak, kebutuhan masyarakat; (2) esensi keilmuan dan keterampilan; (3) pikiran untuk maju dan berkembang; dan (4) perbedaan nilai-nilai sosial.

\section{Kelayakan bahasa}

Komponen kebahasaan ini disajikan menjadi tiga indikator ialah: (1) keterbacaan; (2) analogi dengan kaidah Bahasa Indonesia yang baik dan benar; dan (3) logika berbahasa.

\section{Kelayakan penyajian}

Muatan penyajian ini dipecah menjadi tiga indikator yakni: (1) teknik; (2) materi; dan (3) pembelajaran.

Yudhi Munadi memaparkan bahwa saat mendesain dan membuat bahan ajar interaktif berbasis komputer, harus memerhatikan lima poin berikut sebagai kriteria dalam menilai bahan ajar interaktif, yakni: (1) Kriteria kemudahan navigasi. Suatu program baiknya didesain sesimpel mungkin agar siswa tak harus mengerti komputer lebih dulu; (2) Kriteria kandungan kognisi. Muatan isi program mengasih kemahiran kognitif yang diperlukan siswa; (3) Kriteria integrasi media, artinya media patut memadukan aspek-aspek dan keterampilan lain yang wajib dipelajari. Pembelajaran integrative memfokuskan pada penggabungan beberapa keterampilan berbahasa, mendengarkan, berbicara, menulis, dan membaca; (4) Untuk memunculkan minat siswa aplikasi harus memiliki tampilan yang kreatif, sehingga estetika juga menjadi kriteria; (5) Kriteria penilaian akhir berupa manfaat secara total. Aplikasi yang diciptakan baiknya menyajikan pembelajaran yang dibutuhkan siswa secara penuh. Sehingga saat siswa selesai menggunakan aplikasi itu, ia akan merasa telah belajar sesuatu (Munadi, 2008).

Untuk keterampilan, peneliti mengacu pada Wina Sanjaya. Wina Sanjaya menyatakan bahwa keterampilan ialah kegiatan yang mempunyai maksud tertentu yang membutuhkan manipulasi dan penyelarasan informasi. Keterampilan terbagi menjadi dua, yaitu keterampilan intelektual dan keterampilan fisik. Keterampilan intelektual adalah keterampilan berfikir dengan usaha menggali, mengatur, dan menerapkan 
Vol 1 No 22020 Desember 2020

Jurnal AlphaEuclidEdu

berbagai informasi, berupa data, fakta, konsep, prinsip, maupun teori. Misalnya, keterampilan pemecahan masalah, dengan langkah-langkah yang sistematis, keterampilan mengevaluasi suatu program atau objek, keterampilan mengatur program kegiatan, dan keterampilan menciptakan perencanaan. Keterampilan fisik ialah keterampilan motoric berupa keterampilan menggunakan komputer, keterampilan mengemudi, keterampilan menggambar/melukis, atau memperbaiki suatu alat (Sanjaya, 2013).

Dalam penelitian ini, peneliti menggunakan keterampilan intelektual. Peserta didik dikatakan memiliki keterampilan intelektual jika mampu menerapkan konsep, prinsip maupun teori dalam menentukan luas juring dan panjang busur lingkaran. Untuk materi, peneliti memilih materi lingkaran dengan submateri sudut pusat, panjang busur, dan luas juring lingkaran.

\section{Metode Penelitian}

Dalam penelitian dan pengembangan ini, untuk prosedur pengembangan peneliti mengadopsi teori dari Sugiyono. Berikut penjelasannya.

\section{Potensi dan Masalah}

\section{Potensi}

Dikarenakan penelitian ini ialah pengembangan bahan ajar interaktif, sehingga salah satu alat yang perlu digunakan untuk menerapkan bahan ajar interaktif ini adalah infocus dan laptop. Beberapa sekolah di Pontianak sudah mulai menambahkan fasilitas seperti infocus, laptop / komputer, dll. Sehingga besar potensi peneliti untuk melakukan penelitian disalah satu sekolah di Pontianak.

\section{Masalah}

Matematika seringkali dicap sulit oleh siswa, termasuk bagian sudut pusat, panjang busur, dan luas juring lingkaran, karena siswa sulit mengerjakan soalnya. Oleh karena itu peneliti mengambil materi ini untuk diteliti. Dan guru hanya menggunakan bahan ajar konvensional, tidak membuat bahan ajar sendiri yang menggunakan media. Agar kegiatan belajar dan pembelajaran tidak monoton. Sehingga peneliti melakukan pengembangan bahan ajar interaktif dari materi lingkaran.

\section{Pengumpulan Data}

\section{Pemilihan Sekolah}

Sekolah yang dipilih peneliti ialah SMP Islam Bawari Pontianak. SMP Islam Bawari adalah sekolah yang memakai kurikulum 2013. Sekolah dengan jumlah peserta didik yang cukup, juga memiliki masalah diketerampilan peserta didik berdasarkan dari hasil wawancara dan hasil pengambilan nilai oleh peneliti ketika PPL disana.

\section{Pemilihan materi}

Berdasarkan hasil wawancara dan hasil pengambilan nilai, peserta didik masih belum terampil dalam menyelesaikan masalah yang berkaitan dengan lingkaran.

\section{Analisis Kebutuhan}


Vol 1 No 22020 Desember 2020

Jurnal AlphaEuclidEdu

Peneliti mewawancarai salah seorang guru matematika disekolah tersebut. Hasil pengamatan peneliti ditemukan bahwa banyak siswa yang tidak bisa mengerjakan sebuah persoalan mengenai materi ini. Faktanya terlihat ketika peneliti memberikan pre test kepada peserta didik. Guru juga hanya menggunakan bahan ajar konvensional, yang menurut peneliti kurang memadai. Sehingga siswa banyak yang kurang memahami materi yang disampaikan, terutama pada materi lingkaran. Namun berdasarkan pengalaman peneliti selama melaksanakan PPL disekolah ini, siswa cepat memahami serta fokus pada pelajaran saat peneliti mengajar dengan menggunakan perangkat seperti laptop dan infocus. Siswa merasa tertarik, hal ini jarang dilakukan oleh guru disana.

\section{Desain Produk}

Peneliti membuat rancangan bahan ajar interaktif sesuai indikator pencapaian materi. Kemudian dilanjutkan dengan pembuatan naskah, pembuatan tombol, penambahan audio, penambahan animasi, dan lainnya. Rancangan bahan ajar interaktif sesuai indikator pencapaian materi bisa dilihat dari tabel 1 .

Tabel 1. Rancangan Bahan Ajar Interaktif Sesuai Indikator Pencapaian Materi

\begin{tabular}{|c|c|c|}
\hline No. & Indikator & Interaktif di dalam Bahan Ajar \\
\hline 1. & $\begin{array}{l}\text { Siswa dapat } \\
\text { menunjukkan } \\
\text { hubungan sudut } \\
\text { pusat dengan } \\
\text { panjang busur } \\
\text { lingkaran. }\end{array}$ & $\begin{array}{l}\text { a. Animasi gambar lingkaran yang ada sudut pusatnya, serta } \\
\text { beberapa pertanyaan untuk mengawali materi hubungan sudut } \\
\text { pusat dengan panjang busur lingkaran } \\
\text { b. Gambar tabel yang berisi hubungan antara sudut pusat dengan } \\
\text { panjang busur lingkaran, agar siswa tau apa hubungannya. } \\
\text { c. Tombol rumus yang merupakan akhir dari melakukan kegiatan } \\
\text { dari gambar tabel sebelumnya, agar siswa mengetahui rumusnya. } \\
\text { d. Terdapat contoh soal, serta sebuah tombol yang berisi jawaban } \\
\text { dari contoh soal tersebut }\end{array}$ \\
\hline 2. & $\begin{array}{l}\text { Siswa dapat } \\
\text { menunjukkan } \\
\text { kaitan sudut } \\
\text { pusat dengan } \\
\text { luas juring } \\
\text { lingkaran. }\end{array}$ & $\begin{array}{l}\text { a. Gambar tabel yang berisi kaitan antara sudut pusat dengan } \\
\text { panjang busur lingkaran, agar siswa tau apa hubungannya. } \\
\text { b. Tombol rumus yang merupakan akhir dari melakukan kegiatan } \\
\text { dari gambar tabel sebelumnya, agar siswa mengetahui } \\
\text { rumusnya. } \\
\text { c. Terdapat contoh soal, serta sebuah tombol yang berisi jawaban } \\
\text { dari contoh soal tersebut. }\end{array}$ \\
\hline 3. & $\begin{array}{lr}\text { Siswa dapat } \\
\text { mengerjakan } \\
\text { soal yang } \\
\text { berkaitan } \\
\text { dengan sudut } \\
\text { pusat, sudut } \\
\text { keliling, } \\
\text { panjang busur, } \\
\text { dan luas juring } \\
\text { lingkaran. }\end{array}$ & $\begin{array}{l}\text { a. Terdapat apersepsi yang membahas sedikit tentang panjang } \\
\text { busur serta juring lingkaran. Siswa dapat melihat gambarnya, } \\
\text { jika ingin mengetahui siswa bisa mengklik pada gambar } \\
\text { tersebut, sehingga akan muncul penjelasan dari gambar tersebut. } \\
\text { b. Ada kuis kecil berupa beberapa gambar lingkaran dengan sudut } \\
\text { didalamnya. Siswa memilih yang mana sudut pusat, dan yang } \\
\text { mana sudut keliling. Akan ada respon jika siswa mengklik pada } \\
\text { gambar, yaitu respon berupa gambar salah dan respon berupa } \\
\text { gambar benar. }\end{array}$ \\
\hline
\end{tabular}

\section{Validasi Desain}


Vol 1 No 22020 Desember 2020

Jurnal AlphaEuclidEdu

Peneliti meminta bantuan kepada 2 orang validator, yaitu guru matematika dan dosen pendidikan matematika FKIP Untan. Untuk guru sebagai juru materi dan pembelajaran, sedangkan dosen sebagai juru media, serta materi dan pembelajaran. Untuk menilai bahan ajar interaktif yang dikembangkan, peneliti mengacu kepada BSNP dan Yudhi Munadi. Dari BSNP, peneliti mengambil 3 komponen untuk menilai bahan ajar interaktif yang dikembangkan, yaitu: (1) kelayakan isi; (2) kelayakan bahasa; (3) kelayakan penyajian. Dari Yudhi Munadi lebih kepada media, seperti tombol navigasi, kandungan kognisi, dan lainnya. Lembar validasi ahli menggunakan nilai 1 sampai 4 perbutir penilaiannya, seperti ditampilkan pada tabel 2 .

Tabel 2. Kategori Penilaian Analisis Kelayakan

\begin{tabular}{cc}
\hline Kategori & Skor \\
\hline Sangat baik & 4 \\
\hline Baik & 3 \\
\hline Kurang & 2 \\
\hline Sangat kurang & 1 \\
\hline
\end{tabular}

Dengan kriteria penilaian kevalidan seperti pada tabel 3.

Tabel 3. Kriteria Penilaian Analisis Kelayakan

\begin{tabular}{ll}
\hline Rentang skor & Kategori kevalidan \\
\hline $3<\mathrm{P} \leq 4$ & Sangat valid \\
\hline $2<\mathrm{P} \leq 3$ & Valid \\
\hline $1<\mathrm{P} \leq 2$ & Kurang valid \\
\hline $0<\mathrm{P} \leq 1$ & Tidak valid \\
\hline
\end{tabular}

Lembar validasi dari ahli bahan ajar interaktif dan ahli materi dikumpulkan kemudian dianalisis kevalidannya menggunakan rumus sebagai berikut:

$$
P=\frac{\sum \text { hasil masing }- \text { masing butir }}{\text { banyak butir }}
$$

Sedangkan kriteria penilaian kelayakan bahan ajar interaktif seperti tabel 4.

Tabel 4. Hasil Penilaian Analisis Kelayakan

\begin{tabular}{ll}
\hline Nilai & Keterangan \\
\hline A & Sangat layak, dapat digunakan tanpa revisi. \\
\hline B & Layak, dapat digunakan dengan sedikit revisi. \\
\hline C & Kurang layak, dapat digunakan dengan banyak revisi. \\
\hline D & Tidak layak, tidak dapat digunakan. \\
\hline
\end{tabular}

Bahan ajar yang dibuat dikatakan berkualitas jika penilaian kedua pakar terhadap bahan ajar berada pada kategori valid atau sangat valid serta ahli menyatakan bahan ajar yang dikembangkan layak atau sangat layak.

\section{Revisi Desain}

Perbaikan desain dilaksanakan sehabis validasi. Terdapat sejumlah masukan dari validator untuk memperbaiki bahan ajar interaktif. Bahan ajar interaktif sebelum 
Vol 1 No 22020 Desember 2020

Jurnal AlphaEuclidEdu

direvisi disebut prototype 1 , kemudian setelah direvisi disebut prototype 2. Prototype 2 lah yang akan digunakan dalam ujicoba produk.

\section{Ujicoba Produk}

Hasil dari revisi desain, kemudian diujicobakan di kelas XI SMP Islam Bawari Pontianak. Sebelum mengujicobakan Prototype II, peneliti memberikan Pre-test, dan setelah diujicobakan, peneliti memberikan Post-test. Ujicoba produk dilaksanakan pada tanggal 1 dan 4 November 2019.

\section{Hasil Penelitian dan Pembahasan}

\subsection{Hasil Penelitian}

Bahan ajar interaktif yang sudah disusun tapi belum divalidasi disebut dengan Prototype I. Prototype I selanjutnya divalidasi oleh 2 orang, yaitu dosen sebagai juru media dan materi, serta guru sebagai juru materi. Hasil revisi bahan ajar interaktif disebut dengan Prototype II. Berikut hasil validasi Prototype II pada tabel 5 dan 6.

Tabel 5. Hasil validasi bahan ajar interaktif oleh ahli materi

\begin{tabular}{ccc}
\hline Skor & Kevalidan & Kelayakan \\
\hline 3,94 & Sangat valid & B \\
\hline
\end{tabular}

Tabel 6. Hasil validasi bahan ajar interaktif oleh ahli media

\begin{tabular}{ccc}
\hline Skor & Kevalidan & Kelayakan \\
\hline 3,38 & Sangat valid & B \\
\hline
\end{tabular}

Karena kevalidannya sangat valid, dan kelayakannya B, maka tidak dilakukan revisi lagi oleh peneliti. Hasil dari evaluasi bahan ajar interaktif (Prototype II) diimplementasikan dengan cara uji coba terbatas di SMP Islam Bawari Pontianak. Uji coba dilakukan dengan cara memberikan pre-tes kepada peserta didik sebelum menggunakan Prototype II dan post-tes setelah menggunakan Prototype II dalam pembelajaran materi Lingkaran. Tes tersebut diberikan untuk mengetahui indikatorindikator apa saja yang dimiliki oleh peserta didik. Berikut hasilnya dalam tabel 7.

Tabel 7. Persentase perolehan keterampilan peserta didik

\begin{tabular}{|c|c|c|c|c|}
\hline Keterampilan & Indikator & $\begin{array}{c}\text { Kode } \\
\text { Indikator }\end{array}$ & $\begin{array}{c}\text { Pre-test } \\
(\%)\end{array}$ & $\begin{array}{c}\text { Post-test } \\
(\%)\end{array}$ \\
\hline \multirow{3}{*}{$\begin{array}{l}\text { Keterampilan } \\
\text { Intelektual }\end{array}$} & $\begin{array}{l}\text { Menunjukkan hubungan panjang busur lingkaran } \\
\text { dengan sudut pusat lingkaran. }\end{array}$ & A & $0 \%$ & $58,33 \%$ \\
\hline & $\begin{array}{l}\text { Menunjukkan hubungan luas juring dengan sudut } \\
\text { pusat lingkaran. }\end{array}$ & B & $0 \%$ & $50 \%$ \\
\hline & $\begin{array}{c}\text { Menyelesaikan soal matematika yang berkaitan } \\
\text { dengan hubungan-hubungan antara sudut keliling, } \\
\text { sudut pusat, luas juring, dan panjang busur } \\
\text { lingkaran. }\end{array}$ & $\mathrm{C}$ & $0 \%$ & $20,83 \%$ \\
\hline
\end{tabular}

Prototype II diujicobakan di SMP Islam Bawari Pontianak. Siswa yang mengikuti ujicoba dihari pertama (1 november 2019) sebanyak 24 siswa, namun dihari kedua (4 november 2019) sebanyak 19 siswa, 5 siswa tidak hadir dikarenakan sakit. Ujicoba 
Vol 1 No 22020 Desember 2020

Jurnal AlphaEuclidEdu

dilakukan dengan cara memberikan tes pada saat sebelum dan sesudah penggunaan bahan ajar yang dikembangkan.

\subsection{Pembahasan}

Hasil dari tes yang dilakukan peneliti pada saat sebelum menggunakan bahan ajar interaktif menunjukkan bahwa untuk materi lingkaran, siswa masih mendapat kesulitan saat memahami materi. Hal demikian dapat dilihat pada tabel 7, dengan persentase $0 \%$ disetiap indikatornya. Untuk keterampilan intelektual yang dimiliki oleh siswa masih sangat rendah. Seluruh siswa hanya bisa menuliskan diketahui dan ditanya dari setiap soal. Adapula beberapa siswa yang berusaha untuk mengerjakannya, namun rumus yang digunakan salah. Sehingga salah dalam mengoperasikannya.

Hasil dari tes yang dilakukan peneliti pada saat setelah menggunakan bahan ajar interaktif, menunjukkan bahwa untuk materi lingkaran, siswa bisa memahami dengan baik materi yang disampaikan dengan bahan ajar interaktif. Hal ini dapat dilihat pada tabel 7, untuk perolehan keterampilan intelektual mengalami peningkatan. Hal ini didukung 58,33\% dari 24 siswa, mampu menyelesaikan soal tentang kaitan panjang busur dengan sudut pusat lingkaran. Untuk kemampuan siswa dalam menetapkan kaitan luas juring dan sudut pusat lingkaran, menurut peneliti dalam kategori sedang. Hal ini didukung 50\% dari 24 siswa, mampu menyelesaikan soal mengenai kaitan luas juring dan sudut pusat lingkaran. Sedangkan kemampuan menyelesaikan persoalan terkait hubungan-hubungan antara panjang busur, luas juring, sudut pusat, dan sudut keliling lingkaran. Menurut peneliti masih dalam kategori rendah. Hal ini didukung 20,83\% dari 24 siswa, mampu menyelesaikan soal matematika yang berkaitan dengan hubunganhubungan antara sudut keliling, luas juring, sudut pusat, dan panjang busur lingkaran. Namun mengalami peningkatan dari hasil sebelumnya. Dari uraian tersebut dapat diketahui bahwa, hasil tes yang diperoleh setelah menggunakan bahan ajar interaktif menunjukkan adanya peningkatan dari hasil sebelumnya. Hal tersebut dapat dilihat pada tabel 7, dimana setiap perolehan keterampilan mengalami peningkatan.

\section{Kesimpulan}

Simpulan yang bisa didapat dari penelitian ini adalah: 1) Bahan ajar interaktif yang dikembangkan dinyatakan layak. Bahan ajar ini dinyatakan sangat valid dan layak oleh para ahli, dengan kriteria kelayakan B. 2) Perolehan keterampilan peserta didik mengalami peningkatan setelah menggunakan bahan ajar interaktif yang dikembangkan.

\section{Referensi}

BSNP. (2007). Standar Proses Untuk Satuan Pendidikan Dasar dan Menengah. (Online).(http://bsnpindonesia.org/id/wpcontent/uploads/proses/Permen_41_Th2007.pdf, diakses tanggal 18 Juni 2018).

Munadi, Yudhi. (2008). Media Pembelajaran Sebuah Pendekatan Baru. Jakarta : Gaung Persada Press.

Munir. (2013). Multimedia - Konsep \& Aplikasi dalam Pendidikan. Bandung: Alfabeta. 
Vol 1 No 22020 Desember 2020

Jurnal AlphaEuclidEdu

Prastowo, Andi. (2012). Panduan Kreatif Membuat Bahan Ajar Inovatif. Yogyakarta: DIVA Press.

Prastya, Abi Krida. (2012). Proses Pembelajaran Musik Bagi Kelompok Band Just 4_U di SMA Bopkri 1 Yogyakarta. Yogyakarta : Universitas Negeri Yogyakarta.

Sanjaya, Wina. (2013). Perencanaan dan Desain Sistem Pembelajaran. Jakarta : KENCANA Prenadamedia Group.

Sugiyono. (2017). Metode Penelitian Kuantitatif, Kualitatif dan R\&D. Jakarta : Alfhabeta. 